\title{
The COVID-Kidney Controversy: Can SARS-CoV-2 Cause Direct Renal Infection?
}

\author{
Wei Ling Lau ${ }^{\mathrm{a}}$ Jonathan E. Zuckerman ${ }^{\mathrm{b}} \quad$ Ajay Gupta $^{\mathrm{a}}$ Kamyar Kalantar-Zadeh ${ }^{\mathrm{a}}$ \\ aDivision of Nephrology, Hypertension and Kidney Transplantation, University of California Irvine School of \\ Medicine, Orange, CA, USA; bepartment of Pathology and Laboratory Medicine, David Geffen School of Medicine \\ at University of California Los Angeles, Los Angeles, CA, USA
}

\section{Keywords}

COVID-19 · SARS-CoV-2 · Kidney pathology ·

Immunohistochemistry · Ribonucleic acid

\begin{abstract}
Context: Determining whether SARS-CoV-2 causes direct infection of the kidneys is challenging due to limitations in imaging and molecular tools. Subject of Review: A growing number of conflicting kidney biopsy and autopsy reports highlight this controversial issue. Second Opinion: Based on the collective evidence, therapies that improve hemodynamic stability and oxygenation, or dampen complement activation, are likely to ameliorate acute kidney injury in COVID-19. At this time, whether inhibition of viral infection and replication directly modulates kidney damage is inconclusive.
\end{abstract}

(c) 2021 S. Karger AG, Basel

\section{Introduction}

The severe acute respiratory syndrome coronavirus 2 (SARS-CoV-2) virus outbreak in China at the end of 2019 led to the COVID-19 pandemic, which has claimed over 1 million lives as of October 1, 2020. SARS-CoV-2 demonstrates broad organotropism, that is, cells in many or- gan systems can be directly infected and may act as a reservoir for the virus. Angiotensin-converting enzyme 2 (ACE2) is the functional receptor of SARS-CoV-2 and is expressed in most organs, with highest expression in the kidneys (proximal tubular cells and podocytes) and ileum [1]. Given what is known about ACE2 tissue distribution, the association between acute kidney injury and increased mortality risk in COVID-19, and the urgent need to identify therapeutic targets, it is no surprise that SARS-CoV2 -associated kidney injury is an area of active research.

Several indirect pathways of SARS-CoV-2 acute kidney injury have been elucidated. Kidney pathology shows varying degree of acute tubular injury which includes necrosis when severe, due to a combination of a virus-induced cytokine storm, hypoxemia, and polypharmacy. Complement and coagulation cascades are triggered and may activate each other [2]; however, kidney thrombotic microangiopathy is present only in a subset of cases [3-6]. A few cases of glomerular disease have been reported, with the most common being collapsing glomerulopathy [6-10] which can be associated with high-risk APOL1 gene variants [7-9]. Minimal change disease, membranous glomerulopathy, anti-GBM disease, infection-associated glomerulonephritis, and ANCA-associated vasculitis have also been reported concurrently with SARSCoV-2 infection [3, 6, 7, 11-13].

$\begin{aligned} & \text { karger@karger.com } \\ & \text { www.karger.com/nef }\end{aligned}$
Karger ${ }^{\prime /}$

Kamyar Kalantar-Zadeh

Division of Nephrology, Department of Medicine, University of California Irvine 333 City Blvd West, Suite 400 Orange, CA 92868 (USA) kkz@uci.edu 
Table 1. Summary of studies as of November 30, 2020, that have investigated direct kidney infection by SARS-CoV-2

\begin{tabular}{|c|c|c|c|c|}
\hline Source & $\begin{array}{l}\text { Kidney samples } \\
\text { assessed for } \\
\text { SARS-CoV-2, } n\end{array}$ & $\begin{array}{l}\text { Kidney biopsy } \\
\text { versus } \\
\text { postmortem }\end{array}$ & Methods used to detect SARS-CoV-2 & Details \\
\hline
\end{tabular}

\section{Studies that detected SARS-CoV-2 in kidney tissue}

\begin{tabular}{|c|c|c|c|c|}
\hline $\begin{array}{l}\text { Abbate et al. [18]. } \\
\text { Nephron. Italy }\end{array}$ & 1 & Postmortem & TEM & $\begin{array}{l}\text { Suggestive morphology of coronavirus with } \\
\text { recognizable spikes }\end{array}$ \\
\hline $\begin{array}{l}\text { Bradley et al. [19]. } \\
\text { Lancet. USA }\end{array}$ & $2-4$ & Postmortem & $\begin{array}{l}\text { RT-PCR } \\
\text { TEM } \\
\text { IHC: anti-SARS-S antibody, mouse, } \\
\text { GeneTex }\end{array}$ & $\begin{array}{l}\text { RT-PCR: } 3 / 3 \text { samples positive } \\
\text { TEM: } 2 / 2 \text { samples with viral-like particles, } \\
\text { diameter } 70-100 \mathrm{~nm} \\
\text { IHC: } 2 / 4 \text { samples positive }\end{array}$ \\
\hline $\begin{array}{l}\text { Braun et al. [20]. } \\
\text { Lancet. Germany }\end{array}$ & 63 & Postmortem & RT-PCR & SARS-CoV-2 detected in 38/63 samples \\
\hline $\begin{array}{l}\text { Diao et al. medRxiv } \\
\text { preprint. }{ }^{\dagger} \text { China }\end{array}$ & 6 & Postmortem & $\begin{array}{l}\text { TEM } \\
\text { IHC: anti-SARS-NP antibody from } \\
\text { clone ID: 019, rabbit, Sino Biological }\end{array}$ & $\begin{array}{l}\text { TEM: } 2 / 2 \text { samples with viral-like particles, } \\
\text { diameter } 80-160 \mathrm{~nm} \\
\text { IHC: } 6 / 6 \text { samples positive }\end{array}$ \\
\hline $\begin{array}{l}\text { Farkash et al. [21]. } \\
\text { J Am Soc Nephrol. } \\
\text { USA }\end{array}$ & 1 & Postmortem & TEM & Viral-like particles, diameter $76 \mu \mathrm{m}$ \\
\hline $\begin{array}{l}\text { Puelles et al. [22]. } \\
\text { N Engl J Med. } \\
\text { Germany }\end{array}$ & 6 & Postmortem & RT-PCR, RNA-ISH & SARS-CoV-2 detected in $3 / 6$ samples \\
\hline $\begin{array}{l}\text { Su et al. [23]. } \\
\text { Kidney Int. China }\end{array}$ & $6-9$ & Postmortem & $\begin{array}{l}\text { TEM } \\
\text { IHC: anti-SARS-NP antibody from } \\
\text { clone ID: 019, rabbit, Sino Biological }\end{array}$ & $\begin{array}{l}\text { TEM: } 7 / 9 \text { samples with virus-like particles, } \\
\text { diameter } 65-136 \mathrm{~nm} \text { with } 20-25 \mathrm{~nm} \text { spikes } \\
\text { IHC: } 3 / 6 \text { samples positive }\end{array}$ \\
\hline
\end{tabular}

Studies that were negative for SARS-CoV-2 in kidney tissue

\begin{tabular}{|c|c|c|c|c|}
\hline $\begin{array}{l}\text { Akilesh et al. [3, } 11] \text {. } \\
\text { Am J Kidney Dis. USA }\end{array}$ & 17 & Kidney biopsy & $\begin{array}{l}\text { RNA-ISH ( } 4 \text { biopsies) } \\
\text { TEM (all biopsies) } \\
\text { IHC: anti-SARS-NP antibody, 40143- } \\
\text { T62, Sino Biological ( } 4 \text { biopsies) }\end{array}$ & No SARS-CoV-2 detected \\
\hline
\end{tabular}

\begin{tabular}{|c|c|c|c|c|}
\hline $\begin{array}{l}\text { Golmai et al. [15]. } \\
\text { J Am Soc Nephrol. } \\
\text { USA }\end{array}$ & 12 & Postmortem & TEM & $\begin{array}{l}\text { Clathrin-coated vesicles closely resembling viral } \\
\text { particles, diameter }<20 \text { to }>500 \mathrm{~nm} \text {. No true viral } \\
\text { particles identified. }\end{array}$ \\
\hline $\begin{array}{l}\text { Kudose et al. [7]. } \\
\text { J Am Soc Nephrol. } \\
\text { USA }\end{array}$ & $\begin{array}{l}17 \text { (14 native } \\
\text { kidneys and } 3 \\
\text { transplant } \\
\text { allografts) }\end{array}$ & Kidney biopsy & $\begin{array}{l}\text { RNA-ISH } \\
\text { TEM } \\
\text { IHC } \\
\text { 1. Anti-SARS-NP antibody from } \\
\text { clone ID: 001, rabbit, Sino Biological } \\
\text { 2. Anti-SARS-S2 antibody from clone } \\
\text { ID: 1A9, GTX632604, mouse, } \\
\text { GeneTex }\end{array}$ & No SARS-CoV-2 detected \\
\hline $\begin{array}{l}\text { Larsen et al. [8]. } \\
\text { Kidney Int Rep. USA }\end{array}$ & 1 & Kidney biopsy & RNA-ISH & $\begin{array}{l}\text { No SARS-CoV-2 detected } \\
\text { This study notes that they tested a widely used } \\
\text { IHC antibody under numerous conditions and } \\
\text { found nonspecific staining (anti-SARS-NP } \\
\text { antibody from clone ID: } 019 \text {, rabbit, Sino } \\
\text { Biological) }\end{array}$ \\
\hline $\begin{array}{l}\text { Nasr et al. [9]. } \\
\text { Am J Kidney Dis. USA }\end{array}$ & 13 & Kidney biopsy & $\begin{array}{l}\text { RNA-ISH (1 biopsy) } \\
\text { TEM (all biopsies) }\end{array}$ & No SARS-CoV-2 detected \\
\hline $\begin{array}{l}\text { Peleg et al. [10]. } \\
\text { Kidney Int Rep. USA }\end{array}$ & 1 & Kidney biopsy & $\begin{array}{l}\text { RNA-ISH } \\
\text { TEM }\end{array}$ & No SARS-CoV-2 detected \\
\hline $\begin{array}{l}\text { Rossi et al. [24]. } \\
\text { Kidney Int Rep. Italy }\end{array}$ & 1 & Kidney biopsy & RT-PCR & No SARS-CoV-2 detected \\
\hline $\begin{array}{l}\text { Santoriello et al. [5]. } \\
\text { J Am SocNephrol. USA }\end{array}$ & 10 & Postmortem & RNA-ISH & No SARS-CoV-2 detected \\
\hline
\end{tabular}


Table 1 (continued)

\begin{tabular}{|c|c|c|c|c|}
\hline Source & $\begin{array}{l}\text { Kidney samples } \\
\text { assessed for } \\
\text { SARS-CoV-2, } n\end{array}$ & $\begin{array}{l}\text { Kidney biopsy } \\
\text { versus } \\
\text { postmortem }\end{array}$ & Methods used to detect SARS-CoV-2 & Details \\
\hline
\end{tabular}

IHC, immunohistochemistry; NP, nucleocapsid protein antigen; RNA-ISH, in situ hybridization for detection of target ribonucleic acids within cells; S, spike antigen; RT-PCR, quantitative real-time reverse transcriptase polymerase chain reaction for detection of ribonucleic acids; TEM, transmission electron microscopy. ${ }^{\dagger}$ B. Diao, C.H. Wang, R.S. Wang, Z.Q. Feng, Y.J. Tan, H.M. Wang, et al.: Human kidney is a target for novel severe acute respiratory syndrome coronavirus 2 (SARS-CoV-2) infection (preprint posted online April 10, 2020). medRxiv. doi: 10.1101/2020.03.04.20031120.

Whether direct viral kidney infection occurs with SARS-CoV-2 is a controversial topic. Detection methods include histology, that is, immunohistochemistry (IHC) and transmission electron microscopy (TEM), and ribonucleic acid (RNA) assays, that is, in situ hybridization (RNA-ISH) and quantitative real-time reverse transcriptase polymerase chain reaction (RT-PCR). These methods have inherent limitations.

IHC is valid only if the antibody probe is specific; unfortunately, the commercially available antibodies targeting the SARS-CoV-2 nucleocapsid protein (NP) and spike (S) antigens have not been well validated. In particular, there are concerns with the anti-SARS-NP antibody from clone ID: 019 (Sino Biological, Beijing, China) which has been tested under numerous conditions and has shown nonspecific positive staining in the kidney parenchyma [8]. Moreover, proximal tubules are prone to nonspecific staining of many antibodies due to their intense absorptive capacity.

TEM is challenging as numerous ultrastructures (termed viral-like particles) can mimic viruses [14]. For example, multivesicular bodies in podocyte cytoplasm and clathrin-coated endocytosed vesicles in tubular epithelial cells can have the appearance of a viral corona $[8$, 15]. Several investigations of pre-COVID era biopsies have demonstrated structures morphologically identical to those reported as "SARS-CoV-2 viral particles" [16, 17]. To date, no studies utilizing immunoelectron microscopy for specific viral antigens have been reported.

RNA assays are regarded as the most sensitive and specific, but may be limited if the virus is present below the level of detection. RT-PCR requires homogenization of a tissue sample and may report a false positive if blood is not carefully washed out from the sample, such that the test is actually detecting extracellular circulating virus. Moreover, if tissue samples are obtained at time of autopsy, extent of postmortem autolysis and cell degeneration can complicate interpretation of viral detection assays.

Conflicting studies published between April and November 2020 have provoked an ongoing debate about whether SARS-CoV-2 causes direct kidney infection (Table 1). Several postmortem studies have reported detection of SARS-CoV-2 by electron microscopy, IHC, and/or RNA assays [18-23] (including one medRxiv preprint by Diao et al.). Of note, 2 of these studies utilized the anti-SARS-NP antibody that has raised concerns for a nonspecific signal as discussed above [8]. Puelles et al. [22] provided compelling evidence of punctate staining of viral RNA in glomeruli and tubules by in situ hybridization, and their study included multiple SARS-CoV-2 negative controls. The study by Braun et al. [20] demonstrated successful infection of cultured primate kidney tubular epithelial cells, utilizing homogenized kidney specimens obtained at time of autopsy from SARS-CoV-2 patients; however, the possibility of virus present within residual blood in the kidney tissue could also explain this observation.

Of note, difficulty interpreting RNA-ISH in autopsy tissue has been reported [5] whereby there is rare tubular positivity in both SARS-CoV-2-positive and -negative patients. Thus, in autopsy tissue, RNA-ISH may show false positives, and the threshold as well as characteristics for true positive staining remains to be established.

In contrast, biopsy data from live patients and other autopsy studies have not detected SARS-CoV-2 in the kidney via IHC, RT-PCR, and RNA-ISH [3, 5-11, 15, 24, $25]$. It is possible that the absence of virus detection may 
reflect viral clearing from the kidney as there is frequently delay between initial SARS-CoV-2 infection and either renal biopsy or autopsy. Nonetheless, the negative reports are more consistent with the fact that SARS-CoV-2 is rarely detected in the urine, and urinary levels do not correlate with degree of kidney injury [26, 27]. Furthermore, blood levels are also generally low or nondetectable [27]. These data support the notion that the majority of SARSCoV-2 renal complications likely result from indirect mechanisms, even if a minority of cases may indeed show direct kidney viral infection.

Given this controversy, future studies should utilize rigorous controls including both SARS-CoV-2-positive and -negative tissue. Multimodel detection strategies including IHC, RNA-ISH, and immunoelectron microscopy are warranted. We believe without immunoelectron detection, morphologic evaluation by electron microscopy alone is not sufficient to confirm the presence of viral particles. Fortunately, published validation studies of SARS-CoV-2 antibodies and RNA-ISH are emerging [28] which will help guide the use of appropriate commercially available antibodies and RNA-ISH probes.

Proof of viral replication in human kidney cells remains to be confirmed $[29,30]$. Based on the collective evidence, therapies that improve hemodynamic stability and oxygenation, or dampen complement activation, are likely to ameliorate acute kidney injury in COVID-19. At this time, whether inhibition of viral infection and replication directly modulates kidney damage is inconclusive.

\section{Conflict of Interest Statement}

W.L. Lau has received honoraria and/or support from Fresenius, Hub Therapeutics, Roche, Sanofi, and ZS Pharma. J.E. Zuckerman is a paid consultant for Leica Biosystems. A. Gupta has filed 3 provisional patent applications for use of PGD2 and thromboxane $\mathrm{A} 2$ antagonists, including ramatroban, as a treatment for $\mathrm{CO}$ VID-19 (Application Nos. 63/003,286 filed on March 31, 2020; 63/005,205 filed on April 3, 2020; and 63/027,751 filed on May 2, 2020). K. Kalantar-Zadeh has received honoraria and/or support from Abbott, Abbvie, ACI Clinical (Cara Therapeutics), Akebia, Alexion, Amgen, Ardelyx, Astra-Zeneca, Aveo, BBraun, Chugai, Cytokinetics, Daiichi, DaVita, Fresenius, Genentech, Haymarket Media, Hospira, Kabi, Keryx, Kissei, Novartis, Pfizer, Regulus, Relypsa, Resverlogix, Sandoz, Sanofi, Shire, Vifor, UpToDate, and ZS Pharma.

\section{Funding Sources}

The authors acknowledge funding from NIH NINDS R01NS113337 (W.L.L.) and NIH NIDDK K24-DK091419 (K.K.Z.).

\section{Author Contributions}

W.L.L. and J.E.Z. drafted the manuscript. W.L.L., J.E.Z., A.G., and K.K.Z. made revisions and approved the final manuscript version.

\section{References}

1 Martinez-Rojas MA, Vega-Vega O, Bobadilla NA. Is the kidney a target of SARS-CoV-2? Am J Physiol Renal Physiol. 2020 Jun 1; 318(6):F1454-f62.

2 Batlle D, Soler MJ, Sparks MA, Hiremath S, South AM, Welling PA, et al. Acute kidney injury in COVID-19: emerging evidence of a distinct pathophysiology. J Am Soc Nephrol. $2020 \mathrm{Jul} ; 31(7): 1380-3$.

3 Akilesh S, Nast CC, Yamashita M, Henriksen $\mathrm{K}$, Charu V, Troxell ML, et al. Multicenter clinicopathologic correlation of kidney biopsies performed in COVID-19 patients presenting with acute kidney injury or proteinuria. Am J Kidney Dis. 2021 Jan;77(1):82-93.e1.

4 Jhaveri KD, Meir LR, Flores Chang BS, Parikh R, Wanchoo R, Barilla-LaBarca ML, et al. Thrombotic microangiopathy in a patient with COVID-19. Kidney Int. 2020 Aug;98(2): 509-12.

5 Santoriello D, Khairallah P, Bomback AS, Xu K, Kudose S, Batal I, et al. Postmortem kidney pathology findings in patients with COVID-19. J Am Soc Nephrol. 2020;31(9):2158-67.
6 Sharma P, Uppal NN, Wanchoo R, Shah HH, Yang Y, Parikh R, et al. COVID-19: associated kidney injury: a case series of kidney biopsy findings. J Am Soc Nephrol. 2020;31(9):1948-58.

7 Kudose S, Batal I, Santoriello D, Xu K, Barasch J, Peleg Y, et al. Kidney biopsy findings in patients with COVID-19. J Am Soc Nephrol. 2020;31(9):1959-68.

8 Larsen CP, Bourne TD, Wilson JD, Saqqa O, Sharshir MA. Collapsing glomerulopathy in a patient with COVID-19. Kidney Int Rep. 2020 Jun;5(6):935-9.

9 Nasr SH, Alexander MP, Cornell LD, Herrera LH, Fidler ME, Said SM, et al. Kidney biopsy findings in patients with COVID-19, kidney injury, and proteinuria. Am J Kidney Dis. 2020 Nov 18.

10 Peleg Y, Kudose S, D’Agati V, Siddall E, Ahmad S, Nickolas T, et al. Acute kidney injury due to collapsing glomerulopathy following COVID-19 infection. Kidney Int Rep. 2020 Apr 28;5(6):940-5.

11 Akilesh S, Nast CC, Yamashita M, Henriksen $\mathrm{K}$, Charu V, Troxell ML, et al. Multicenter clin- icopathologic correlation of kidney biopsies performed in COVID-19 patients presenting with acute kidney injury or proteinuria. Am J Kidney Dis. 2021 Jan;77(1):82-93.e1.

12 Prendecki M, Clarke C, Cairns T, Cook T, Roufosse C, Thomas D, et al. Anti-glomerular basement membrane disease during the $\mathrm{CO}$ VID-19 pandemic. Kidney Int. 2020 Sep; 98(3):780-1.

13 Uppal NN, Kello N, Shah HH, Khanin Y, De Oleo IR, Epstein E, et al. De Novo ANCA-associated vasculitis with glomerulonephritis in COVID-19. Kidney Int Rep. 2020 Nov;5(11): 2079-83.

14 Calomeni E, Satoskar A, Ayoub I, Brodsky S, Rovin BH, Nadasdy T. Multivesicular bodies mimicking SARS-CoV-2 in patients without COVID-19. Kidney Int. 2020 Jul;98(1):233-4.

15 Golmai P, Larsen CP, DeVita MV, Wahl SJ, Weins A, Rennke HG, et al. Histopathologic and ultrastructural findings in postmortem kidney biopsy material in 12 patients with AKI and COVID-19. J Am Soc Nephrol. 2020; 31(9):1944-7. 
16 Cassol CA, Gokden N, Larsen CP, Bourne TD. Appearances can be deceiving: viral-like inclusions in COVID-19 negative renal biopsies by electron microscopy. Kidney360. 2020; 1(8):824-8.

17 Roufosse C, Curtis E, Moran L, Hollinshead M, Cook T, Hanley B, et al. Electron microscopic investigations in COVID-19: not all crowns are coronas. Kidney Int. 2020 Aug; 98(2):505-6.

18 Abbate M, Rottoli D, Gianatti A. COVID-19 attacks the kidney: ultrastructural evidence for the presence of virus in the glomerular epithelium. Nephron. 2020;144(7):341-2.

19 Bradley BT, Maioli H, Johnston R, Chaudhry I, Fink SL, Xu H, et al. Histopathology and ultrastructural findings of fatal COVID-19 infections in Washington State: a case series. Lancet. 2020 Aug 1;396(10247):320-32.

20 Braun F, Lütgehetmann M, Pfefferle S, Wong $\mathrm{MN}$, Carsten A, Lindenmeyer MT, et al. SARS-CoV-2 renal tropism associates with acute kidney injury. Lancet. 2020 Aug 29; 396(10251):597-8.
21 Farkash EA, Wilson AM, Jentzen JM. Ultrastructural evidence for direct renal infection with SARS-CoV-2. J Am Soc Nephrol. 2020 Aug;31(8):1683-7.

22 Puelles VG, Lütgehetmann M, Lindenmeyer MT, Sperhake JP, Wong MN, Allweiss L, et al. Multiorgan and renal tropism of SARSCoV-2. N Engl J Med. 2020 Aug 6;383(6): $590-2$.

23 Su H, Yang M, Wan C, Yi LX, Tang F, Zhu $\mathrm{HY}$, et al. Renal histopathological analysis of 26 postmortem findings of patients with $\mathrm{CO}$ VID-19 in China. Kidney Int. 2020 Jul;98(1): 219-27.

24 Rossi GM, Delsante M, Pilato FP, Gnetti L, Gabrielli L, Rossini G, et al. Kidney biopsy findings in a critically ill COVID-19 patient with dialysis-dependent acute kidney injury: a case against "SARS-CoV-2 nephropathy." Kidney Int Rep. 2020 Jul;5(7):1100-5.

25 Xia P, Wen Y, Duan Y, Su H, Cao W, Xiao M, et al. Clinicopathological features and outcomes of acute kidney injury in critically ill COVID-19 with prolonged disease course: a retrospective cohort. J Am Soc Nephrol. 2020; 31(9):2205-21.
26 Wang L, Li X, Chen H, Yan S, Li D, Li Y, et al. Coronavirus disease 19 infection does not result in acute kidney injury: an analysis of 116 hospitalized patients from Wuhan, China. Am J Nephrol. 2020;51(5):343-8.

27 Wang W, Xu Y, Gao R, Lu R, Han K, Wu G, et al. Detection of SARS-CoV-2 in different types of clinical specimens. JAMA. 2020 May 12;323(18):1843-4.

28 Best Rocha A, Stroberg E, Barton LM, Duval EJ, Mukhopadhyay S, Yarid N, et al. Detection of SARS-CoV-2 in formalin-fixed paraffin-embedded tissue sections using commercially available reagents. Lab Invest. $2020 \mathrm{Jul}$ 9:1-5.

29 Delsante M, Rossi GM, Gandolfini I, Bagnasco SM, Rosenberg AZ. Kidney involvement in COVID-19: need for better definitions. J Am Soc Nephrol. 2020;31(9):2224-5.

30 Vijayan A, Humphreys BD. SARS-CoV-2 in the kidney: bystander or culprit? Nat Rev Nephrol. 2020 Dec;16(12):703-4. 